\title{
Cognitieve dissonantie
}

Als je in de kindertandheelkunde vraagt waar het in het vakgebied om draait, is iedereen het erover eens: preventie is de speerpunt. Maar de praktijk is anders. In Nederland werd volgens Vektis in 20144891 keer de prestatiecode A20 (algehele anesthesie) gedeclareerd voor kinderen tussen de 0 en 18 jaar. In dat jaar waren de kosten per prestatie voor A20 bij kinderen gemiddeld $€ 688$ (exclusief de kosten voor de mondzorg!). Dat komt neer op een gemiddelde behandelduur van meer dan anderhalf uur. Je vraagt je af hoe dat kan als preventie het hoofddoel is. Er zijn immers mogelijkheden te over om narcosebehandeling te vermijden, dan wel te beperken.

Overtreatment is in de kindertandheelkunde een alledaags verschijnsel. Dat komt doordat de overheid dit kosteloos vergoedt en de Inspectie te weinig man-

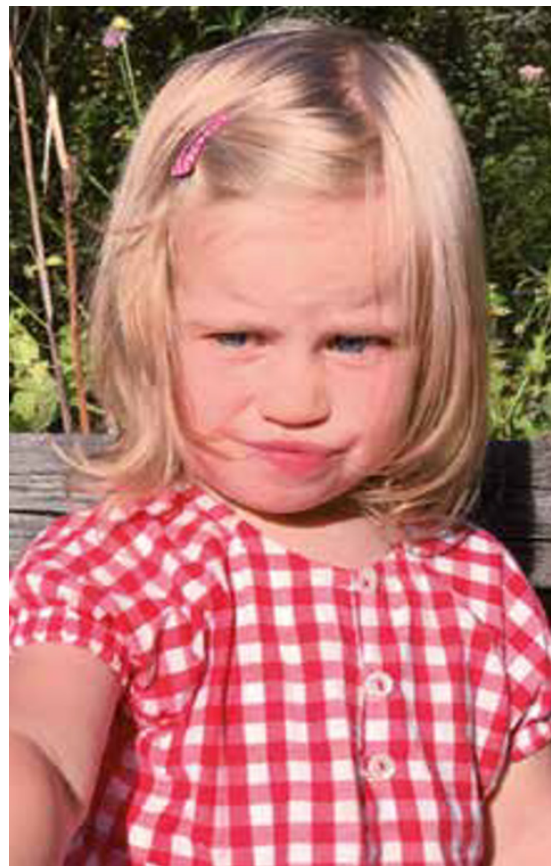

Cognitieve dissonantie? je hele leven doet is het lastig om van koers te veranderen.'

Over de narcosebehandelingen in de kindertandheelkunde hoor je ook dergelijke vergoelijkende opmerkingen. Zo wordt onprofessioneel gedrag kleiner gemaakt dan het is. Het gaat hier over zorgverleners die al heel lang behandelingen uitvoeren waarvan de gezondheidswinst niet is aangetoond. Die behandelingen zijn soms behoorlijk belastend voor de patiënt. De $N R C$ publiceerde in 2010 uit een onderzoek dat was uitgevoerd in opdracht van het ministerie van Volksgezondheid: 'Ziekenhuizen verspillen 900 miljoen tot 1,3 miljard euro per jaar doordat ze onnodige operaties uitvoeren. Dat is 7 à 9 procent van de totale uitgaven van ziekenhuizen. Belangrijkste oorzaak is dat specialisten die relatief veel opereren achterhaalde behandelmethoden hanteren. "Ze doen routineus dingen die kracht heeft om na te gaan of de indicatiestelling altijd terecht is. De indicatie 'pulpotomie' wordt onder narcose sneller dan nodig gesteld op basis van onbetrouwbare criteria. Zo worden in een alom bekende pedodontologiepraktijk per jaar meer dan 1600 MTA-pulpotomieën bij melkelementen gedeclareerd, en ze zijn daar nog trots op ook. Recent werd in een onderzoek aangetoond dat kinderen na een pulpotomie onder narcose meer napijn ervaren dan na behandeling zonder pulpotomie; geen reden om trots op te zijn.

Niemand vraagt zich echter af wat het verschil is tussen verregaande overtreatment en kindermishandeling. Als je de kwestie aan de orde stelt beginnen sommigen te schelden omdat ze lijden aan een stoornis als gevolg van gebrekkige impulsbeheersing (kleutergedrag!). Anderen ervaren de discussie als ongemakkelijk, want iedereen is tegen kindermishandeling. Maar men vindt het overdreven om verregaande overtreatment bij kinderen als kindermishandeling te kwalificeren. Met andere woorden: dan treedt het verschijnsel van 'cognitieve dissonantie' in werking. Men maakt de als onaangenaam ervaren feiten kleiner dan ze zijn.

Op Wikipedia staat: 'Cognitieve dissonantie is de onaangename spanning die iemand ervaart bij tegenstrijdige overtuigingen, ideeën of opvattingen of als er wordt vastgesteld dat diegene in strijd met de eigen overtuiging handelt. In zijn boek A Theory of Cognitive Dissonance uit 1957 stelde Leon Festinger dat mensen streven naar het verkleinen van die dissonanties en daarvoor hun opvattingen of gedrag aanpassen.' Van artsen die het trommelvlies bij kinderen doorprikken terwijl dat geen gezondheidswinst oplevert, werd een tijd geleden door een professor in De Volkskrant gezegd: 'Als je dingen al ze vele jaren geleden hebben geleerd tijdens hun medische opleiding", aldus een onderzoeker. "Binnen het ziekenhuis corrigeren specialisten hun collega's niet", zo bleek uit het onderzoek.' Alleszins begrijpelijk dat het belastende feit kleiner wordt gemaakt, want het voorspelbare gevolg is dat de boodschapper van de onwelgevallige boodschap het heeft gedaan ...

Onlangs werd mij op de ledenvergadering van de Nederlandse Vereniging voor Kindertandheelkunde het woord ontnomen toen ik meldde dat er in de narcosebehandeling bij kinderen schandalige zaken gebeuren. Ik had geen namen genoemd, maar de voorzitter verklaarde na de vergadering dat ze zich persoonlijk door mijn opmerking aangesproken voelde. Had ik het daarom niet mogen zeggen?

En nu de feiten: Als je een tik uitdeelt naar een kind is dat strafbaar, maar als je een kind onnodig blootstelt aan narcose word je daarvoor royaal betaald door de zorgverzekeraars. En narcosebehandeling verleent je zelfs status in de pedodontologie.

René Gruythuysen
Dr. R.J.M. Gruythuysen is onderzoeker en PAOT-docent kindertandheelkunde/cariologie. Zijn aandachtsvelden in onderzoek zijn behandeling van diepe cariës en niet-restauratieve caviteitsbehandeling (NRC). Hierover publiceerde hij eerder in TP 47 casussen. Thans is hij tevens begeleider van het project 'Kindertandheelkunde' in de mondzorgpraktijk Tandzorg.nl te Rotterdam. 